\title{
THE EFFECT OF SERVICE QUALITY AND COMMUNITY RELATIONSHIP ON THE SATISFACTION OF MOTOR VEHICLES TAXPAYERS AT THE OFFICE WITH SAMSAT JEMBER
}

\author{
Ponang Undaghi $\mathbf{T}^{1}$ \\ Suwignyo Widagdo ${ }^{2}$ \\ Muhaimin Dimyati ${ }^{3}$
}

\author{
Higher Education of Economic Mandala \\ Email: ponang.57@gmail.com
}

\begin{abstract}
This study aims to determine the effect of service quality and public relations on the satisfaction of motor vehicle taxpayers in Samsat Jember. The type of research used is Explanatory Research using survey methods. The population in this study is the people of Jember who have motorized vehicle taxpayers. The sampling technique used was a non-probability sampling technique, namely the Accidental Sampling approach. The sample in this study were 100 respondents. The data analysis method used is multiple linear regression analysis. The results of this study indicate that the significant value of the service quality variable on the satisfaction of motorized vehicle taxpayers in Samsat Jember is 0.008 smaller than (0.05), this means that the service quality variable has a significant effect on community satisfaction at the Jember Samsat Joint Office. Then the significant value of the public relations variable on the satisfaction of motorized vehicle taxpayers in the Jember Samsat is 0.000 smaller than (0.05), this means that the public relations variable also has a significant effect on public satisfaction at the Jember Samsat Joint Office.
\end{abstract}

Keywords: Service Quality, Public Relations, Satisfaction

\section{INTRODUCTION}

Public services are a series of activities in an effort to meet service needs in accordance with the laws and regulations for every citizen for goods and services, as well as administrative services provided by public service providers. Law No. 25 of 2009. Public services provided to the community should always reflect good service quality, considering that every public service provided is often used as an indicator by the community in measuring the level of success of a government, both central and local governments.

One of the existing public service providers is SAMSAT. This institution serves various community needs related to the payment of motor vehicle taxes such as 
re-approval of the annual STNK and replacement of the five-year STNK. Payment of motor vehicle tax is an obligation owned by every motorized vehicle holder. (Harispiandi, 2016). In Law No. 22 of 2009 concerning traffic, it is stated that every motorized vehicle operated on the road must be equipped with a valid vehicle number (STNK) and motorized vehicle number (TNKB). If the STNK and TNKB owned have expired, the owner of the motorized vehicle may be subject to sanctions.

The SAMSAT joint office is a public service provider institution that is the focus of the community in paying their motor vehicle tax. For this reason, this institution must continue to provide quality public services and refer to the pattern of excellent service, namely: fast, easy, cheap, precise and transparent. Effective and efficient public sector institutional reform encourages public service institutions to continue to improve services in line with the demands of society in this digitalization era. This service improvement is expected to be able to motivate taxpayers to comply with regulations and make regular tax payments. A person's motivation in making motor vehicle tax payments is strongly influenced by public satisfaction with the quality of services and public relations carried out by SAMSAT. If a service unit is equated with a company that produces products or services and a taxpayer has the same position as a consumer as a user of goods or services, then the satisfaction obtained as a result of service quality and public relations will lead to repurchase behavior, which means that Taxpayers will comply with the regulations for paying motor vehicle taxes which must be paid annually. Awaludin, (2017).

Jember is a district with a population of 2,398,000 million, Jember in numbers (2019). This large number of residents certainly has the potential for a large number of motorized vehicles in Jember Regency. In 2017 the number of motorized vehicle tax objects reached 60,248 for cars and 498,642 for motorcycles. This number continues to increase every year until in 2019 the number of motor vehicle tax objects reached 82,279 units for car objects and 639,631 units for motorcycle objects (Dispenda, 2019). Along with the growth in the number of motorized vehicles in Jember Regency, the potential for increasing the volume of motor vehicle tax payments will also increase. This of course requires the function of the motor vehicle tax service (PKB) at SAMSAT Jember to always improve the quality of its services to get good public satisfaction

Satisfaction can be obtained if the service provided is in accordance with the expectations of the community. Currently, the quality of services at SAMSAT Jember is adequate with the existence of an integrated service system, but this system has not been running effectively according to the original plan. It can be seen that there are still many people who queue for a long time when paying taxes and the fact that payments for motorized vehicles cannot be completed in a short time. Another factor that can affect people's satisfaction is public relations. As a public service institution, the presence of a public relations officer is important to increase public satisfaction, especially as a medium for delivering information to the public regarding the obligation to pay motor vehicle taxes.

SAMSAT Jember has carried out activities to improve the quality of services and public relations with various programs such as: 1. The main Samsat Jember there are 2 main Samsat namely Samsat Patrang, JL Dr Subandi 234 Patrang Jember and Samsat Kaliwates, JL Lotus no 10-11 Kaliwates Jember. The main Samsat is the parent of all existing services, starting with annual taxes, changing licenses, changing vehicle names, incoming mutations, 
outgoing transfers, and processing new vehicles. 2. Samsat Srikandi service. This is done at 06.00-08.00 at the Jember city market where the staff is female. 3. Samsat Hurray (Home care) for taxpayers who cannot come to Samsat to pay for vehicles. With this program, taxpayers only need to telephone or sms the Samsat call center, then the Samsat officer will come to the taxpayer's place to print the payment notice. 4. Mobile Samsat Car Service. This program serves taxpayers who are far from the main Samsat and is scheduled from Monday to Saturday. This program also serves at night with locations in the Jember city square and in front of the Jember Sun Mall. 5. Samsat payment points Jember in collaboration with Bank Jatim Jember as a place to provide convenience to taxpayers so that taxpayers do not have to go far to the main Samsat to pay taxes. 6. Samsat Corner Roxy Jember provides convenience in paying taxes while shopping the same as the Toxy Squar Jember shopping store. 7. Samsat Drive Thru pays taxes, you don't need to get out of the vehicle 8. Samsat GoCek (Go Check physically $\}$ is a service used for tax payers who have time to change their STNK but the data is damaged / can't run, check data for vehicle registration, tax checks can be done by telephone Samsat call center, later Samsat officers will come to physically check the frame and engine numbers to validate vehicle data 9. PPOb with pT pos is an annual vehicle tax payment that can be done at all post offices 10. PPOb with Indomaret, Alfamaret, just link , Tokopedia, Griya Rumah BTN is the convenience of paying the East Java plate tax online that can be done throughout Indonesia 11. E-samsat jatim.go.id is a program to support the convenience of paying the East Java plate tax online which can be done without being limited in time and place.

The programs mentioned above are currently not able to run optimally. From the results of field observations, there are several public opinions that are not good on the quality of services and public relations carried out by SAMSAT Jember. The opinion states that the processing of motor vehicle taxes still takes a long time, so people tend to use the services of brokers. In addition, the available facilities are not functioning optimally and there are still some service personnel who are less responsive in helping the community to obtain information related to the motor vehicle tax payment process. This study aims to determine the effect of service quality and public relations on the satisfaction of motor vehicle taxpayers in Samsat Jember.

\section{RESEARCH METHODS}

The type of research used is Explanatory Research. Explanatory Research is research that aims to find new relationships. In addition, this study also aims to test the causal relationship and test the relationship between several variables through hypothesis testing. This study uses a survey method, where data is collected based on respondents' answers from a list of questions (questionnaires) that are proposed. The population in this study is the people of Jember who have motorized vehicle taxpayers.

The sampling technique used in this study is a non-probability sampling technique, namely the Accidental Sampling approach. Accidental Sampling is a technique of determining samples based on chance, that is, anyone who coincidentally meets a researcher can be used as a sample if it is deemed that the person who happened to be met is suitable as a data source (Sugiyono, 2012: 67). Hair (2006) suggests that the number of research samples used to determine the causal relationship between independent variables and the dependent variable is at least 5-10 times the number of variables analyzed or question indicators. 
This study uses 10 indicators analyzed. So in this study the sample used was 100 respondents, the result of multiplying the number of indicators multiplied by 10 (10 $\mathrm{X} 10=100)$.

The method of data analysis in this study used multiple linear regression analysis. The test was carried out with multiple linear regression analysis because it used 2 independent variables which aimed to determine the effect of service quality and public relations variables on community satisfaction in paying motor vehicle taxes. The method of data collection was done by simple random sampling technique. After the data is collected, then the data is processed to determine the validity and reliability of the research instrument. To fulfill the assumption of multiple linear regression analysis, the classical assumption test is carried out which includes the data normality test, multicollinearity test and heteroscedasticity test. After the data meets the classical assumption test, then hypothesis testing is carried out. Hypothesis testing is used to determine the significance of each independent variable on the dependent variable contained in the model.

\section{RESULT ANALYSIS \\ Validity and Reliability Test}

Based on the results of the validity test that has been carried out, it is known that all the statement items for the variables of service quality, public relations and community satisfaction each have an r-count value greater than the $r$ table $(0.197)$. In addition, the significance value for all statement items shows a number smaller than 0.05. Thus, all indicators in the variables of service quality, public relations and community satisfaction can be proven valid. In other words, the statement in this study can be declared feasible to be used in research.

In addition, in testing the reliability of the data, Cronbach's Alpha values on the variables of service quality, public relations and community satisfaction respectively show the numbers $0.772,0.850$. And 0.857 . Thus, it can be concluded that all indicators used as a measuring tool for service quality variables, public relations and community satisfaction can be trusted because each has a Cronbach alpha value of more than 0.60. This means that the measurement results are relatively consistent even though the question is given twice or more to different respondents so that this questionnaire can be used for further research using the same variables.

\section{Normality Test}

The results of the data normality test can be seen in the following table:

\begin{tabular}{llr}
\multicolumn{2}{c}{ Table 1. Data normality test results } \\
\hline $\mathrm{N}$ & $\begin{array}{c}\text { Unstandardized } \\
\text { Residual }\end{array}$ \\
Normal Parameters ${ }^{\text {a,b }}$ & Mean & 100 \\
& Std. Deviation & $0 \mathrm{E}-7$ \\
Most Extreme Differences & Absolute & Positive \\
& Negative &, 067 \\
Kolmogorov-Smirnov Z &, 066 \\
Asymp. Sig. (2-tailed) &,- 047 \\
a. Test distribution is Normal. &, 060 \\
b. Calculated from data. &, 215 \\
\hline
\end{tabular}

Based on the table above, it is known that the significance value of the unstansardized residual is 0.215 . These results indicate that the significance value of the unstansardized 
residual is greater than 0.05 , thus indicating that the residual value of the data spreads according to a normal distribution and the regression model is feasible to use because it meets the assumption of normality.

\section{Multicollinearity Test}

The results of the multicollinearity test can be seen in the following table:

Table 2. Multicollinearity Test

\begin{tabular}{|c|c|c|c|c|c|c|c|c|}
\hline \multirow{2}{*}{\multicolumn{2}{|c|}{ Model }} & \multicolumn{2}{|c|}{$\begin{array}{l}\text { Unstandardized } \\
\text { Coefficients }\end{array}$} & \multirow{2}{*}{$\begin{array}{c}\text { Standardized } \\
\text { Coefficients } \\
\text { Beta }\end{array}$} & \multirow[t]{2}{*}{$t$} & \multirow[t]{2}{*}{ Sig. } & \multicolumn{2}{|c|}{$\begin{array}{c}\text { Collinearity } \\
\text { Statistics }\end{array}$} \\
\hline & & B & Std. Error & & & & Tolerance & VIF \\
\hline \multirow[b]{2}{*}{1} & (Constant) & 4,605 & 1,334 & & 3,452 & ,001 & & \\
\hline & $\begin{array}{l}X 1 \\
X 2\end{array}$ & $\begin{array}{l}, 063 \\
, 285\end{array}$ & $\begin{array}{l}, 023 \\
, 057\end{array}$ & $\begin{array}{l}248 \\
, 463\end{array}$ & $\begin{array}{l}2,702 \\
5,045\end{array}$ & $\begin{array}{l}, 008 \\
, 000\end{array}$ & $\begin{array}{l}, 747 \\
, 747\end{array}$ & $\begin{array}{l}1,338 \\
1,338\end{array}$ \\
\hline
\end{tabular}

a. Dependent Variable: $Y$

Based on the table above, it shows that the tolerance value of the independent variables, namely the service quality and public relations variables, is 0.747 , which is greater than 0.01 , while the VIF result is 1.338 , which is smaller than 10, so from these results it can be concluded that there is no multicollinearity in the independent variables.

\section{Heteroscedasticity Test}

The results of the heteroscedasticity test can be seen in the following table:

Table 3 Heteroscedasticity Test

\begin{tabular}{llrrrrr}
\hline Model & \multicolumn{2}{c}{$\begin{array}{l}\text { Unstandardized } \\
\text { Coefficients }\end{array}$} & \multicolumn{2}{c}{$\begin{array}{c}\text { Standardized } \\
\text { Coefficients } \\
\text { Beta }\end{array}$} & t & Sig. \\
& B & Std. Error & Sta & & \\
\hline \multirow{2}{*}{1 (Constant) } & 1,283 &, 626 & & 2,049 &, 043 \\
& Kualitas Layanan &, 004 &, 011 &, 039 &, 335 &, 738 \\
& Public Relation &,- 017 &, 028 &,- 071 &,- 608 &, 545 \\
\hline
\end{tabular}

a. Dependent Variable: abs_RES

From the test results shown in table above, it can be seen that the service quality variable does not occur heteroscedasticity because the value of $\mathrm{sig}>0.05$ is 0.738 . The public relations variable does not occur heteroscedasticity because the value of sig> 0.05 is 0.545 . Thus it can be concluded that the data obtained for all independent variables do not occur heteroscedasticity symptoms.

\section{Multiple Linear Regression Analysis}

Multiple linear regression analysis is a process of systematically estimating what is most likely to happen in the future based on past and present information so that errors can be minimized. The results of multiple linear regression analysis can be seen in the following table:

Table 4 Multiple Linear Regression Analysis

\begin{tabular}{|c|c|c|c|c|c|c|c|}
\hline \multirow[t]{2}{*}{ Model } & \multicolumn{2}{|c|}{$\begin{array}{c}\text { Unstandardized } \\
\text { Coefficients }\end{array}$} & $\begin{array}{c}\text { Standardized } \\
\text { Coefficients }\end{array}$ & \multirow[t]{2}{*}{$t$} & \multirow[t]{2}{*}{ Sig. } & \multicolumn{2}{|c|}{$\begin{array}{c}\text { Collinearity } \\
\text { Statistics }\end{array}$} \\
\hline & $\mathrm{B}$ & Std. Error & Beta & & & Tolerance & VIF \\
\hline (Constant) & 4,605 & 1,334 & & 3,452 & ,001 & & \\
\hline $\mathrm{X} 1$ & ,063 & ,023 & , 248 & 2,702 & ,008 & ,747 & 1,338 \\
\hline $\mathrm{X} 2$ & ,285 & ,057 & ,463 & 5,045 & ,000 & ,747 & 1,338 \\
\hline
\end{tabular}

a. Dependent Variable: $Y$ 
Based on the table above, it is known that the t-count value on the service quality variable is 2.702 which is greater than the ttable of 1.66. In addition, the significant value of the service quality variable is 0.008 which is smaller than (0.05). This shows that the service quality variable has a significant effect on community satisfaction. In

\section{INTERPRETATION}

Based on the results of hypothesis testing that has been done previously, it states that service quality has a significant effect on community satisfaction at the Jember Samsat Joint Office. This means that the higher the level of service quality provided, the greater the community satisfaction at the Jember Samsat Joint Office.

The service quality variable in this study was measured in accordance with the service principle as stipulated in the Men.Pan Decree No.63/Kep/M.Pan/7/2003 regarding the community satisfaction index which was grouped into 3 dimensions, namely the implementation of service procedures, the ability of service personnel and availability of facilities and infrastructure. Service quality is the expected level of excellence and control over the level of excellence to meet customer desires.

Based on the results of the study found that Samsat Jember has applied the principle of good service. This is indicated by the community's satisfaction with the implementation of service procedures at the Jember Samsat Joint Office. The implementation of good service procedures is indicated by the convenience for the public in understanding the technical and administrative requirements of each type of service, clarity of information about the service procedures provided, speed in completing each type of service and the addition, the table above can also be seen that the t-count value on the public relations variable is 5.045 which is greater than the ttable of 1.66. In addition, the significant value of the public relations variable is 0.000 , which is smaller than (0.05). This shows that the public relations variable has a significant effect on people's satisfaction.

imposition of affordable fees for service recipients.

In addition, good service quality is also seen from the ability of service personnel. In the findings of the research, the majority of the community believes that service officers at the Jember Samsat Joint Office have discipline and consistency according to the officer's working time and have good responsibilities in completing the service process. In addition, the community also believes that service providers have competent knowledge, expertise, skills and experience and feel that the behavior and attitudes of officers in providing services are very good and fair, and carry out service functions in accordance with specified service standards.

Another factor that indicates a good quality of service is the availability of facilities and infrastructure. In the findings of the research, the majority of the community considered that the Jember Joint Samsat Office had a clean and tidy service room, the availability of tax payment forms provided by the Jember Joint Samsat Office was very complete and the security level in the Jember Joint Samsat office was very good. In addition, the community also believes that the physical facilities supporting the service process at the Jember Samsat Joint Office are very complete and have a very sophisticated (computerized) information system. This is what causes that the quality of service affects the satisfaction 
of the people of the Office with the Jember Samsat.

The results of this study support the findings of research conducted by Fathoni (2011) which states that service quality which consists of reliability, responsiveness, assurance, empathy and tangible effect on the satisfaction of motorized vehicle taxpayers in Batu City. These results also support the findings of research conducted by Rahardjanto, (2015) which states that service quality has an influence on motor vehicle taxpayer satisfaction at the South Jakarta Samsat Joint Office. In addition, Harispiandi (2015) states that service quality has a significant effect on community satisfaction. These results also support the findings of research conducted by Prianggono, et al (2011) and Pratiwi (2017) which states that service quality has a significant effect on community satisfaction.

The findings in this study support the results of the community satisfaction survey conducted by the Jember Samsat itself. The survey results explain that the average value of the community satisfaction index is 86.72 (Appendix 8). This shows that the index of community satisfaction with the services provided by the Jember Samsat Office is very good. The report states that the factors that influence the community satisfaction index include: 1) The proactive attitude of officers in providing information to taxpayers is our effort to make it easier for taxpayers to understand the procedures for managing motorized vehicle administration,

2) Implementation of monev (monitoring and evaluation) to maintain the quality of services provided to taxpayers, and Commitment of the Head of UPT. PPD Jember with all family planning personnel. Samsat in carrying out excellent services through superior services in accordance with SOPs.

The findings in the field found that the quality of services provided by the Jember
SAMSAT Office was very good, however, the Jember Samsat still needed an improvement in service quality considering that the Jember Samsat Joint Office was ISO 9001:2015 certified, but the survey results for the 60th period 2020 Satisfaction Survey Society (SKM) based on the level of opinion and level of interest still has a value of 86.72. In addition, the Jember Samsat Joint Office should always improve the performance of service officers, improve facilities and infrastructure on an ongoing basis and make every effort to implement the work commitments contained in the mutually agreed Vision and Mission.

Based on the results of hypothesis testing that has been done previously, it also states that public relations has a significant effect on community satisfaction at the Jember Samsat Joint Office. This means that the higher the public relations activities carried out by the Jember Samsat, the more people's satisfaction with the Jember Samsat Joint Office will increase. The public relations variable in this study was measured by 4 indicators, namely the ability to convey information, community service activities, the ability to use media and the affordability of information.

Based on the results of the study, it was found that the Jember Samsat had implemented the principles of good public relations implementation. This is indicated by the existence of a positive public perception of the delivery of information on motor vehicle tax management services to the public through the activities of holding seminars, exhibitions, sponsorships, and others. In addition, SAMSAT Jember has had community awareness programs, such as external services, socialization, coordination and joint operations. This program can help to facilitate the dissemination of information to the public about information on motor vehicle tax management services. In terms of media 
utilization, SAMSAT Jember has good capabilities. This can be seen from the majority of respondents who answered strongly agree and agree with the statement that "SAMSAT Jember has good abilities in designing and utilizing existing media". In addition, SAMSAT Jember is also able to deliver news that can be easily reached by all levels of society. These factors can be a consideration for the community in giving a good assessment of the public relations performance carried out by the Jember Samsat Joint Office.

The results of this study support the findings of research conducted by Zuliatin (2016) with his findings which state that personal selling, direct selling and public relations have a simultaneous effect on customer satisfaction at BMT UGT Sidogiri KCP Kanigoro Blitar. These results also support the research of Handani (2014) with its findings which state that the performance of public relations and customer relationship management has a significant effect on customer satisfaction at the Islamic Hospital of Surakarta "Yarsis". Krismiyati T (2017) also states that the performance of public relations significantly influences patient satisfaction at RSUD Dr. Moewardi in Surakarta.

\section{CONCLUSION}

Based on the results of the discussion in the previous chapter, it can be concluded that the service quality variable has a significant effect on community satisfaction at the Jember Samsat Joint Office. This means that the higher the level of service quality provided, the greater the community satisfaction at the Jember Samsat Joint Office. The results of this study also show that the public relations variable also has a significant effect on community satisfaction at the Jember Samsat Joint Office. This means that the higher the public relations activities carried out by the Jember Samsat, the more people's satisfaction with the Jember Samsat Joint Office will increase. Based on the conclusion above which explains that the level of community satisfaction is influenced by the quality of service and public relations. However, there is still a need to improve the quality of services and public relations activities considering that the Jember Samsat Joint Office already has an ISO 9001:2015 certificate.

\section{REFERENCES}

Fathoni, 2011, Pengaruh Kualitas Pelayanan terhadap Kepuasan Wajib Pajak Kendaraan Bermotor di Kota Batu, Jurnal Aplikasi Manajemen Vol 9 No 3

Handani, W. (2014). Pengaruh Kinerja Public Relations Dan Customer Relations Management Terhadap Kepuasan Pelanggan Rumah Sakit Islam Surakarta “ Yarsis .” (07730075)

Krismiyati, T. (2017). Pengaruh Kinerja Public Relations Dan Customer Relations Terhadap Kepuasan Pasien Rsud Dr . Moewardi Di. Journal of Business \& Industrial Marketing

Prianggono, J. D. M. (2011). Pengaruh Kualitas Pelayanan Terhadap Kepuasan Wajib Pajak Dalam Penerbitan Surat Tanda Nomor Kendaraan Di Samsat Balikpapan. Jurnal Makna, 1(2), 62

Rahardjanto dkk, 2015, Analisis Pengaruh Kualitas Pelayanan terhadap Kepuasan Wajib Pajak Kendaraan Bermotor pada Kantor Bersama Samsat Jakarta Selatan, Repository Universitas Bina Nusantara

Sugiyono. 2012. Statistika untuk Penelitian. Bandung : Alfabeta 